\title{
O GESTO PARTICULAR E A FEBRE DO MUNDO: um Ensaio Sobre a Ambivalente Confluência do Consumo Sustentável e as Mudanças do Clima
}

\author{
Antônio Carlos Efing \\ Mestre e doutor pela PUCPR; professor-titular da PUCPR \\ e professor da Escola da Magistratura do Paraná; membro \\ do Instituto dos Advogados do Paraná; advogado militante \\ em Curitiba. ace@eradv.com.br

\section{Rullyan Levi Maganhati Mendes} \\ Mestrando em Direito pela PUCPR. Especialista em Direito \\ Constitucional pela Academia Brasileira de Direito Consti- \\ tucional (ABDConst) e em Sociologia Política pela Univer- \\ sidade Federal do Paraná (UFPR). rullyan@hotmail.com
}

Resumo:

0 presente estudo tem por objetivo contextualizar o consumo sustentável a partir de um de seus motes argumentativos mais recentes, o das mudanças do clima. Na persecução de um desenvolvimento sustentável e, por consequência, de um consumo com ele compatível, o nexo clima-consumo foi internalizado no discurso do poder público, da iniciativa privada e do terceiro setor. 0 sentido geral de consumo sustentável atualmente oferecido, contudo, revela-se ambivalente, servindo, em certa medida, como reforço aos níveis de consumo já praticados.

\section{Palavras-Chave:}

Sustentabilidade. Mudanças climáticas. Consumo sustentável. Direito das relações de consumo. Direito ambiental.

\section{PARTICULAR GESTURE AND THE WORLD FEVER:}

an Assay on the Ambivalent Confluence of Sustainable Consumption and Climate Changes

\section{Abstract:}

This study aims to contextualize sustainable consumption from one of its most recent argumentative motes, the one of climate changes. In pursuit of sustainable development and, therefore, consumption compatible with it, the climate-consumption nexus was internalized 
in the public power, in the private sector and the third sector discourses. However, the general sense of sustainable consumption currently offered seems to be ambivalent, serving in a large extent, as reinforcement to consumption levels already practiced.

\section{KEYWORDS:}

Sustainability. Climate changes, Sustainable consumption. Right of consumer relations. Environmental law.

Recebido em: 26/6/2017

Aceito em: 11/8/2017

\section{Sumário:}

1 Introdução. 20 desenvolvimento sustentável. 3 A convergência entre as mudanças climáticas e o consumo sustentável. 3.1 As mudanças do clima. 3.2 0s modos de consumo. 3.3 0 clima e 0 consumo sustentável. 3.3.1 0 poder público, o clima e o consumo sustentável. 3.3.2 A iniciativa privada, o clima[ e o consumo sustentável. 3.3.3 0 terceiro setor, o clima e 0 consumo sustentável. 40 consumo sustentável. 4.1 A ambivalente confluência do consumo sustentável e as mudanças do clima. 5 Considerações finais. 6 Referências. 


\section{INTRODUÇÃO}

Há uma situação inconteste: "Somos uma população confinada na superfície de uma esfera, com recursos limitados, flutuando no espaço gelado, aquecida pelo Sol". ${ }^{1}$ E - embora, em regra, afirmaçôes muito amplas mereçam relativização - talvez seja possível afirmar que em nenhum outro momento histórico foram tão arriscadas as interferências humanas no ambiente, ou, em outros termos, jamais foram consumidos e degradados tantos recursos naturais (até mesmo atmosféricos) como na atualidade. É o tempo da "incrivelmente humana crise ambiental". ${ }^{2}$ Muito se reitera, como imagem-símbolo do esgotamento dos ecossistemas, que daqui a pouquíssimo tempo serão necessários dois planetas Terra para a manutenção dos atuais padrôes de consumo. Ainda assim, cabe recordar, o planeta de agora - o único que se habita - tem destinatários futuros.

Entre outros, certamente, existe nesse cenário um dilema de base que envolve circunstâncias de lida intrincada: de um lado, a necessidade (ontológica?) do humano por uma impressão de segurança (jurídica, inclusive); de outro, a dificuldade (cultural?) do humano em aceitar limites. Insistindo no psicologismo, é dizer: nesse momento, a existência humana está emaranhada na história das coisas adquiridas - particularmente acumuladas - ou das que se gostaria de adquirir, e, em contrapartida, existem restriçóes físicas ambientais que desestabilizam a continuidade dessa dinâmica (classificada, por alguns, como predatória e feliz).

Compreende-se, portanto, que padróes hiperbólicos de consumo (globalmente falando) comprometem a qualidade da vida - de todas as formas de vida, existentes e potenciais. Dessa constatação ganha força o intuito de orientar os padrôes de consumo para um modelo finalmente racional, o consumo sustentável. Como afirma Sodré,

1 DIAS, Genebaldo Freire. Mudança climática e você: cenários, desafio, governança, oportunidades, cinismos e maluquices. São Paulo: Gaia, 2014. p. 19.

2 SOUZA FILHO, Carlos Frederico Marés de. De como a natureza foi expulsa da modernidade. Revista Crítica de Direito, São Paulo, v. 66, n. 5, p. 88-104, p. 90, ago./dez. 2015. 
[...] o ato de consumir, em tese, se opóe à ideia de preservar e é preciso repensar esta relaçáo. Por outro lado, a ideia ingênua de preservar corre o risco de esquecer a necessidade do homem de consumir. Repensar esta sociedade de uma forma realística é absolutamente imprescindível. Não se trata de opor preservação ao consumo, mas de buscar uma saída que pode ser denominada consumo sustentável. ${ }^{3}$

Como se sabe, porém, tudo cabe na linguagem, especialmente a universalizada (empregada, a propósito, neste estudo). Assim como se dá com a narrativa do desenvolvimento sustentável, a construção de um consumo sustentável, naquele apoiado, desde logo já está atravessada por uma série de sentidos e ambivalências. A complexificar o seu manejo como "arma semântica", ${ }_{4}^{4}$ surge a questão das mudanças climáticas antropogênicas (causadas pela ação humana), consideradas “o sinal mais eloquente" ${ }^{5}$ na soma dos processos de degradação ambiental. Clima e consumo tornaram-se, hoje, parceiros temáticos, e, vinculados no discurso, estão espraiados no consumo essencial ou perdulário - e no subconsumo, vale dizer - de cada indivíduo.

Nesse sentido, objetiva este estudo o delineamento do conceito de consumo sustentável aproximado da temática das mudanças climáticas. Para tanto, utilizando-se da metodologia descritiva, aborda-se inicialmente a concepção de desenvolvimento sustentável, contexto-base para a proposta de um consumo sustentável. Pontua-se, posteriormente, o trato reservado no Brasil ao nexo clima-consumo pelo poder público, a iniciativa privada e o terceiro setor, demonstrando a relevância argumentativa que essa combinação temática passou a ter no gesto de consumir sustentavelmente. Versa-se, por último, acerca do consumo sustentável como categoria em construção e, em seguida, assinala-se a existência de certa ambivalência em seu sentido prático.

3 SODRÉ, Marcelo Gomes. Padrôes de consumo e meio ambiente. Revista de Direito do Consumidor, São Paulo: RT, v. 31, p. 29, jul./set. 1999.

4 KEMPF, Hervé. Como os ricos destroem o planeta. Tradução Bernardo Ajzenberg. São Paulo: Globo, 2010. p. 34.

5 LEFF, Enrique. Discursos sustentáveis. Tradução Silvana Cobucci Leite. São Paulo: Cortez, 2010. p. 134. 


\section{DESENVOLVIMENTO SUSTENTÁVEL}

Em uma simples busca a qualquer dicionário salta aos olhos que a combinação do verbete "desenvolvimento", associado a progresso, crescimento e exploração, e do verbete "sustentabilidade", atrelado à manutenção, preservação e ao sustento, ostenta uma aparente contradição, é talvez um oxímoro, ou seja, uma uniāo de palavras em confronto que reforçam outra ideia, exterior a elas. O elemento de conexão entre desenvolvimento e sustentabilidade, quer se crer, está nos limites físicos à exploração do ambiente. Em termos gerais, foi a partir da industrialização que o padrão de vida mundial passou da mera subsistência para a abundância, a ponto de gerar o insight acerca da escassez dos recursos naturais.

No plano internacional, o conceito de desenvolvimento sustentável foi (e segue sendo) afirmado a partir de importantes documentos no âmbito da Organização das Naçóes Unidas (ONU), como foi o caso do relatório "Nosso Futuro Comum”, em 1987. A Conferência das Nações Unidas sobre o Meio Ambiente e Desenvolvimento - também denominada "Rio-92", "Eco-92" ou "Cúpula da Terra" - foi o ponto de inflexão na cronologia ambiental, que, por sua vez, remonta a outro, 20 anos antes, a Conferência de Estocolmo, em 1972, o primeiro grande evento sobre o tema meio ambiente.

De acordo com o "Nosso Futuro Comum”, desenvolvimento sustentável seria aquele que atende às necessidades presentes sem comprometer a possibilidade de que as geraçóes futuras satisfaçam as suas próprias necessidades. ${ }^{6}$ Trata-se, assim, de uma conceituação igualitária e transgeracional, apontando que "a preservação da biosfera é uma prática social eminentemente prospectiva, [em que] o futuro passa a ser o novo locus". ${ }^{7}$ Amplamente aceita, essa formulação recebeu algumas críticas, pois deixa alguns termos em aberto, como a expressão "necessidades", que, em determinada perspectiva, seguramente se contrapóe a alguns dos meandros do uni-

${ }^{6}$ COMISSÃO MUNDIAL SOBRE MEIO AMBIENTE E DESENVOLVIMENTO. Nosso futuro comum. Rio de Janeiro: FGV, 1988.

7 RAMOS JR., Dempsey Pereira. Meio ambiente e conceito jurídico de futuras geraçōes. Curitiba: Juruá, 2012. p. 392. 
verso dos consumidores, não somente àqueles perdulários. De todo modo, importa referir que o desenvolvimento sustentável abarca a ideia de intergeracionalidade, de repensar o consumo para torná-lo menos irracional em termos ambientais.

O conceito de desenvolvimento sustentável depende do conceito de consumidor consciente. Este reflete a necessidade de os consumidores (de produtos e serviços) passarem a ser agentes de "controle crítico" do desenvolvimento sustentável, e isto só pode ser possível desapegando-se dos conceitos individualistas a respeito do que se consome, do que se utiliza, porque isto tem influência direta em todos os cidadãos e no próprio meio ambiente. ${ }^{8}$

A Constituição Brasileira de 1988 incorporou o conceito do "Nosso Futuro Comum" no seu artigo 225, o que trata sobre o meio ambiente. No entendimento de Freitas, inexiste contradição na expressão desenvolvimento sustentável. Segundo ele, no caso brasileiro,

[...] trata-se do princípio constitucional que determina, com eficácia direta e imediata, a responsabilidade do Estado e da sociedade pela concretizaçáo solidária do desenvolvimento material e imaterial, socialmente inclusivo, durável e equânime, ambientalmente limpo, inovador, ético e eficiente, no intuito de assegurar, preferencialmente de modo preventivo e precavido, no presente e no futuro, o direito ao bem-estar. ${ }^{9}$

É nesse sentido também a posiçáo do Supremo Tribunal Federal, compartilhada pelo Superior Tribunal de Justiça, ao definir o estatuto jurídico do desenvolvimento sustentável como princípio de natureza constitucional, integrador da questão ambiental nas estratégias e políticas de ordem social e econômica.

Do “Nosso Futuro Comum”, em 1987, passando pela promulgação da Constituição Brasileira, até hoje, aliado ao crescente peso que passou a ter nas políticas nacionais, internacionais, transnacionais e corporativas, a ideia de um desenvolvimento sustentável teve inumeráveis definiçóes e interpretaçóes, salientando-se que,

8 EFING, Antônio Carlos. Fundamentos do direito das relações de consumo: consumo e sustentabilidade. 3. ed. Curitiba: Juruá, 2011. p. 125.

9 FREITAS, Juarez. Sustentabilidade: direito ao futuro. 2. ed. Belo Horizonte: Fórum, 2012. p. 41. 
em 2002, o documento final elaborado na Cúpula Mundial sobre Desenvolvimento Sustentável afirmou que o conceito deve estar apoiado em três pilares interdependentes, por assim dizer: o econômico, o social e o ambiental, convergindo temas como a degradação ambiental, o crescimento populacional, a decadência urbana, a pobreza, o desperdício, a saúde e a violência contra os direitos humanos.

A “Agenda 2030", proposta em setembro de 2015 pela agora denominada Cúpula das Naçôes Unidas Sobre Desenvolvimento Sustentável, por sua vez, ressignificou novamente o conceito de desenvolvimento sustentável, de modo que passou a ser considerado em sua pluridimensionalidade, sem "amesquinhá-lo à ingênua narrativa de que ele só teria três dimensões", ${ }^{10}$ em alusão ao tripé econômico, social e ambiental anteriormente referido. Sobressai dessa nova perspectiva a tardia "descoberta" oficial de que o macrobem ambiental - o planeta e todos os seus elementos com vida e sem vida (como o ar) - é uno e indivisível, e, por essa razão, exigente de uma perspectiva conjunta de desenvolvimento sustentável, "integrando diferentes áreas (pensar no conjunto), mas agindo no individual”. ${ }^{11}$

Estreitamente relacionada com o desenvolvimento sustentável está a noção de sustentabilidade, que "pode ser definida como o destino pretendido do desenvolvimento sustentável”. ${ }^{12}$

A sustentabilidade não pode ser medida com exatidão, pois é um fim orientador. Alguns indicadores, contudo, permitem balizar açôes que intencionam atingi-la, oferecendo alguma medida para o equilíbrio entre a qualidade de vida (função das condiçóes de consumo) e a capacidade do ambiente de suportar impactos (tanto de extração dos recursos quanto de depósito de rejeitos). Entre eles, citam-se os mais conhecidos, o da análise do ciclo de vida de bens e serviços, do espaço ambiental e o da "pegada ecológica", igualmente criticados como simplistas e tendentes à precificação.

\footnotetext{
${ }^{10}$ VEIGA, José Eli da. Para entender o desenvolvimento sustentável. São Paulo: 34, 2015. p. 147.

${ }^{11}$ SILVA, Christian Luiz da. Proposta de um modelo de monitoramento e avaliação do desenvolvimento sustentável. In: SILVA, Christian Luiz da (Org.). Desenvolvimento sustentável: um modelo analítico integrado e adaptativo. 2. ed. Petrópolis, RJ: Vozes, 2008. p. 18.

${ }^{12}$ DIAS, Reinaldo. Sustentabilidade: origem e fundamentos; educaçấo e governança global; modelo de desenvolvimento. São Paulo: Atlas, 2015. p. 44.
} 
A sustentabilidade, defendida per se ou como informadora de um desenvolvimento sustentável, é também objeto de muitas formulaçóes, como fraca, forte, superforte, entre outras, correntes que contemplam o quanto o ambiente é condicionante da expansão econômica. Em análise própria, por exemplo, Boff ${ }^{13}$ divide a sustentabilidade em categorias como retórica, ausente, enganosa, fraca, insuficiente, possível, viável e desejada, partindo da "armadilha do sistema [...] que mascara a pobreza que ele mesmo produz", até um elogio ao ideal dos povos andinos, recentemente constitucionalizado, que, ao menos em tese, "convida a não consumir mais do que o ecossistema consegue suportar". Pondera, no fim, que, independentemente da visão que se tenha do que é sustentabilidade,

a ideia motora é esta: não é correto, não é justo e nem ético que, ao buscarmos os meios para a nossa subsistência, dilapidemos a natureza, destruamos biomas, envenenemos os solos, contaminemos as águas, poluamos os ares e destruamos o sutil equilíbrio do Sistema Terra e do Sistema Vida.

Nesse mesmo sentido, para Veiga, ${ }^{14}$ o desenvolvimento sustentável é "a mais generosa visão do futuro", pois

[...] em seu âmago está uma visão de mundo dinâmica, na qual transformação e adaptação são inevitáveis, mas dependem de elevada consciência, sóbria prudência e muita responsabilidade diante dos riscos e, principalmente, das incertezas.

Tratando-se de incertezas, entre os grandes temas na área de sustentabilidade ambiental discutidos multilateralmente, destaca-se o das mudanças climáticas decorrentes do aquecimento global, reiterado na recente "Agenda 2030".

As mudanças climáticas globais em curso têm vínculo com o futuro, são resultado de decisóes exercidas no presente e produto de escolhas sociais e, em vista disso, redimensionam as percepções de risco, espaço e tempo, são transfronteiriças e transtemporais, sobrepujam espaços geográficos determinados por ignorarem divisões político-jurídicas.

${ }^{13}$ BOFF, Leonardo. Sustentabilidade: o que é - o que não é. 2. ed. Petrópolis, RJ: Vozes, 2013. p. 46, 62, 64.

${ }^{14}$ VEIGA, José Eli da. Para entender o desenvolvimento sustentável. São Paulo: 34, 2015. p. 9, 46. 
Discutidas com maior visibilidade há menos de uma década, aos poucos as mudanças climáticas transformaram-se em uma questão do universo vivido pelos consumidores, particularmente associadas ao incentivo da prática de um consumo sustentável, capaz de mitigá-las em determinada escala. Estabeleceu-se, assim, um nexo entre o gesto individual dos consumidores - a escolha - e os eventos climáticos advindos de um planeta febril. ${ }^{15}$ Como afirma Gilding ao analisar esse movimento, "enfrentamos ameaças agora que não são filosóficas, mas intensamente práticas e pessoais. Náo se trata de equilíbrio entre proteçáo ambiental e crescimento econômico, mas de uma relação causal entre os dois fatores". ${ }^{16}$

Assim, com o avanço da discussão sobre as mudanças climáticas antropogênicas, os pontos de convergência entre consumo e ambiente passaram a ser problematizados de modo mais articulado, como se verá na sequência.

\section{A CONVERGÊNCIA ENTRE AS MUDANÇAS CLIMÁTICAS E 0 CONSUMO SUSTENTÁVEL}

\subsection{AS MUDANÇAS DO CLIMA}

Provavelmente um dos problemas ambientais mais debatidos nas últimas décadas, o aquecimento global é o aumento da temperatura média do planeta em decorrência das emissóes humanas ou antrópicas de Gases de Efeito Estufa (GEEs) na atmosfera. Desde a Revoluçáo Industrial a humanidade tem emitido, a cada ano, GEEs em uma proporção maior do que a Terra consegue absorver. ${ }^{17}$

${ }^{15}$ Conforme reportagem do Instituto Socioambiental, "a metáfora da febre é pertinente. O mundo, com febre, além de mais quente, está desordenado; seus processos biológicos, tal qual num acesso de altas temperaturas em um organismo vivo, estão comprometidos; as causas podem ser múltiplas e suas consequências, desconhecidas e incomensuráveis". Ver em: INSTITUTO SOCIOAMBIENTAL. O mundo está com febre. Disponível em: <https://www.socioambiental.org/pt-br/noticias-socioambientais/o-mundo-esta-com-febre>. Acesso em: 20 jul. 2016.

${ }^{16}$ GILDING, Paul. A grande ruptura: como a crise climática vai acabar com o consumo e criar um novo mundo. Tradução Renato Aguiar. Rio de Janeiro: Apicuri, 2014. p. 53 (grifo do autor).

${ }^{17}$ MATIAS, Eduardo Felipe Pérez. A humanidade contra as cordas: a luta da sociedade global pela sustentabilidade. São Paulo: Paz e Terra, 2015. p. 31. 
O efeito estufa leva ao aquecimento global que conduz às mudanças do clima. O efeito estufa antrópico, que se soma ao natural, ocorre em razão do aumento da concentração de determinados gases na atmosfera - como o dióxido de carbono $\left(\mathrm{CO}_{2}\right)$, o metano $\left(\mathrm{CH}_{4}\right)$ e o óxido nitroso $\left(\mathrm{N}_{2} \mathrm{O}\right)$, por exemplo - que, entre outras complexas repercussóes, fazem com que a temperatura global se eleve, visto que retêm calor na atmosfera. $\mathrm{O}$ aquecimento global, por sua vez, diz respeito à elevação da temperatura média da Terra, causada muito provavelmente pelo efeito estufa, que afeta o clima. Por último, as mudanças climáticas são alteraçóes sofridas no sistema climático terrestre. Como alguns gases de efeito estufa, a exemplo do dióxido de carbono, ficam na atmosfera por décadas e até séculos, os emitidos hoje seguirão provocando mudanças no clima em um processo que não pode ser revertido de uma hora para outra. ${ }^{18}$

Recortada como objeto científico, a atmosfera, em sentido lato, pode ser analisada em duas escalas, como tempo e clima. O tempo meteorológico é local e imediato; o clima, geral e duradouro, é o somatório de inúmeros eventos meteorológicos, considerados em períodos variantes de, no mínimo, 30 a 50 anos. Tempo, portanto, "é o conjunto de valores que, em um dado momento e em um determinado lugar, caracteriza o estado atmosférico"; clima, por sua vez, é "um conjunto de eventos de tempo semelhantes, mais ou menos estáveis, que resulta em condiçóes relativamente permanentes" ${ }^{19}$ Em linguagem poética, é possível afirmar que "clima é o que esperamos; tempo é o que recebemos". ${ }^{20}$ Assim, na exposição desse cenário, as mudanças climáticas representam perturbaçóes nos padrôes históricos do clima global e regional, causando um acréscimo na variabilidade de eventos atmosféricos extremos.

Nos últimos 150 anos, mais ou menos, os gases de efeito estufa na atmosfera aumentaram progressivamente com a expansão da produção industrial. A temperatura média mundial elevou-se $0,74^{\circ} \mathrm{C}$ desde 1901 . Sabemos por estudos

\footnotetext{
${ }^{18}$ MILLER JR., G. Tyler. Ciência ambiental. Tradução All Tasks. São Paulo: Cengage Learning, 2008. p. $422-427$.

${ }^{19}$ STEINKE, Ercília Torres. Climatologia fácil. São Paulo: Oficina de Textos, 2015. p. 16-17.

${ }^{20}$ AZEVEDO, Ana Lucia. Novos tempos: os homens que enfrentavam um furacão, o rapaz que surfava nuvens e outras histórias de tempestades no Brasil. Rio de Janeiro: Zahar, 2012. p. 12.
} 
geológicos que as temperaturas do planeta oscilaram no passado, e que essas oscilaçóes se correlacionaram com o teor de $\mathrm{CO}_{2}$ na atmosfera. Mas os dados mostram que em nenhuma ocasião, nos últimos 650 mil anos, o teor de $\mathrm{CO}_{2}$ no ar foi tão alto quanto agora. ${ }^{21}$

Em virtude dessas consideraçóes, como resultado do percurso e embate (retórico e político) das distintas mentalidades acerca da questão ambiental, são notórios os diversos protocolos internacionais, sistemas de certificaçóes empresariais, políticas e legislaçóes ambientais nacionais que têm sido desenvolvidos nas últimas décadas como forma de regrar a utilização e proteçáo dos recursos naturais, bem como seus respectivos ecossistemas e sistemas sociais relacionados. Ainda assim, porém, o meio ambiente segue como objeto de incongruências "entre o que é decidido e o que é praticado", 22 gerando "incertezas incompatíveis com as necessidades da sociedade atual". ${ }^{23}$

As mudanças do clima ganharam repercussão quando incorporadas à pauta política, ${ }^{24}$ o que se deu com a criação pela ONU em parceria com a Organizaçáo Meteorológica Mundial, em 1988, do Painel Intergovernamental sobre Mudanças Climáticas, mais conhecido por sua sigla em inglês, IPCC (Intergovernmental Panel on Climate Change), com a função de reunir e avaliar informaçóes técnicas relevantes para a compreensão das bases científicas do risco das mudanças do clima, ou, em síntese, ser responsável pelo vigente estado da arte do assunto.

As causas antropogênicas do aquecimento global já haviam sido sugeridas nos primeiros relatórios do IPCC (em 1990, 1995 e 2001), porém, no limite, o aquecimento global somente se tornou um tema de preocupação mundial a partir da publicação do quarto relatório, em 2007, que estabeleceu, com clareza, o nexo entre a ação humana e o aquecimento do planeta. Em uníssono, a propósito, os

${ }^{21}$ GIDDENS, Anthony. A política da mudança climática. Tradução Vera Ribeiro. Rio de Janeiro: Jorge Zahar, 2010. p. 38.

${ }^{22}$ FERREIRA, Jorge Borges. Meio Ambiente. In: MOTTA, Márcia (Org.). Dicionário da terra. 2. ed. Rio de Janeiro: Civilização Brasileira, 2010. p. 295.

${ }^{23}$ LEITE, José Rubens Morato. Dano ambiental: do individual ao coletivo extrapatrimonial. 3. ed. São Paulo: Revista dos Tribunais, 2010. p. 25.

${ }^{24}$ MACHADO, Paulo Affonso Leme. Direito ambiental brasileiro. 23. ed. São Paulo: Malheiros, 2015. p. 626. 
dois últimos relatórios (o quarto, de 2007, e o quinto, de 2013) concluíram que "a influência antrópica no sistema climático é clara" e "o aquecimento do sistema climático é inequívoco".

Ainda que em nada a revelação fosse surpreendente, pode-se afirmar que "pela primeira vez houve um culpado". ${ }^{25}$

Não obstante, apesar das pesquisas do IPCC serem "endossadas em unanimidade pelas maiores instituiçóes científicas dos principais países do mundo" ${ }^{26}$ e, no que interessa a este estudo, ter sido o IPCC referenciado pelo ordenamento jurídico brasileiro, ressalta-se que inexiste conformidade plena sobre a efetiva contribuição antrópica na mudança global do clima. Para os que defendem a ausência de evidências científicas sobre o efeito antropogênico climático, o que existe, grosso modo, são oscilaçóes e variabilidades climáticas naturais do equilíbrio dinâmico da Terra. ${ }^{27}$

\subsection{OS MODOS DE CONSUMO}

Existindo pela primeira vez um culpado, não tardou para que, com nova razão argumentativa (convergente com as já existentes), o estilo de vida da humanidade, genericamente considerado, fosse afetado.

Em linhas bastante gerais, costuma-se estabelecer que a partir da metade do século passado o universo do consumo ganhou prevalência na articulação entre crescimento econômico e indústria cultural massificada, passando a se constituir como complexo elemento de mediação social, desvinculado da urgência da precisão estrita e atrelado a um valor simbólico, a uma competitiva lógica de diferenciação

${ }^{25}$ PAZ, Josi. O clima do consumo: a sociedade de consumidores no debate sobre a mudança climática. 2012. 559 p. Tese (Doutorado em Sociologia) - Universidade de Brasília, Brasília, 2012. p. 77.

${ }^{26}$ GORE, Al. Nossa escolha: um plano para solucionar a crise climática. Tradução Fabiana de Carvalho, Maria Augusta Tedesco e Otávio Albuquerque. Barueri, SP: Manole, 2010. p. 24.

${ }^{27}$ Cf., por exemplo, um rol de cientistas "céticos do aquecimento global" e seus respectivos argumentos em: ONÇA, Daniela de Souza. "Quando o sol brilha, eles fogem para a sombra": a ideologia do aquecimento global. $2011.557 \mathrm{f}$. Tese (Doutorado em Geografia) - Universidade de São Paulo, São Paulo, 2011. 
por status. ${ }^{28}$ Ganhou ainda mais robustez e amplitude com o surgimento de novas tecnologias e a globalização dos mercados, tornando-se ainda mais incrementado em seu estágio atual, na afirmação, por assim dizer, de "uma governança global construída pelos mercadores", ${ }^{29}$ uma mundialização da demanda. De modo sintético, "[...] a economia está impulsionada para o consumo" 30 e este forma atualmente uma poderosa ligaçáo entre os espaços econômicos e socioculturais.

Como saldo, em maior ou menor medida, ocorre a expansão da mentalidade do "ter" em detrimento do "ser", um quase inquestionável mote de ação em um cenário de sedutoras reiteraçóes e de volumoso desperdício, um "presente hedonista veiculado pelas mitologias festivas dos objetos e dos lazeres", ${ }^{31}$ que, se supóe, assegure ao humano o efeito de menor incompletude existencial e recursos de poder. Ao mercado, por sua vez, coube a veloz renovação planejada dos bens e serviços em seus provisórios usos sociais, mantenedora do modelo de produção objetivado.

O consumo advém, portanto, de uma condição natural (biológica, de sobrevivência); o consumismo, de uma construçáo social moderna, quando o consumo (exagerado, contínuo e naturalizado), revestido de outros significados, assume papel essencial na sociedade de produtores - suas fronteiras, contudo, utilizando a terminologia baumaniana, quase sempre podem ser descritas como líquidas, ou, em jargão jurídico, costumam depender do caso concreto.

Ademais o consumo pode ser problematizado a partir de inúmeras perspectivas - ecológica, econômica, jurídica, sociológica, mercadológica - e certamente nenhuma pode ser desconsiderada e ser, por si só, suficiente.

É importante notar as várias conotaçôes que pode assumir a palavra consumo, $\mathrm{e}$ que na própria economia a diversidade aparece. Consumo é o processo pelo qual se deriva utilidade de um bem ou de um serviço. De uma forma mais generalizada, também se pode descrever o consumo como a atividade de adquirir bens

\footnotetext{
${ }^{28}$ BAUDRILLARD, Jean. A sociedade de consumo. 2. ed. Lisboa: Ediçôes 70, 2010. p. 50.

${ }^{29}$ BOFF, Leonardo. A grande transformação: na economia, na política, na economia. Petrópolis, RJ: Vozes, 2014. p. 41.

${ }^{30}$ ALIER, Joan Martínez. O ecologismo dos pobres. São Paulo: Contexto, 2007. p. 215.

${ }^{31}$ LIPOVETSKY, Gilles. A felicidade paradoxal: ensaio sobre a sociedade de hiperconsumo. São Paulo: Companhia das Letras, 2007. p. 42.
} 
e serviços com o intuito de auferir satisfaçóes. O CDC [Código de Defesa do Consumidor], ao deixar em aberto o conceito de consumo decide por permitir a ingerência de todas as teorias que, de alguma maneira, contribuem para o entendimento do que seja consumo: seja na destruição do bem, na destruição da utilidade, ou simplesmente na venda e, também, estendendo o entendimento aos bens móveis, imóveis, materiais, imateriais, além, é claro, dos serviços que também estão regulamentados. ${ }^{32}$

Do mesmo modo que o consumo é polissêmico, o consumidor também é um sujeito de múltiplas leituras possíveis, de modo que deve ser considerado de maneira abrangente e, sempre que possível, contextualizado.

Assim, interessa ponderar que, a depender de como é praticado, o consumo pode gerar danos diretos ao ambiente, pois os sistemas naturais devem fornecer continuamente matéria-prima e, ao mesmo tempo, receber os resíduos dos processos produtivos. E, por derradeiro, é sempre oportuno ter em mente "que menos de um quarto da população mundial consome $80 \%$ dos bens e mercadorias produzidos", 33 o que estabelece modos de consumo, relaçóes que transitam entre a necessidade e o desperdício. Para Portilho, ${ }^{34}$ esse cenário só é possível na manutenção de um quadro de injustiça social e insustentabilidade ecológica. Além disso, provavelmente a "harmonização entre consumo e meio ambiente não acabará com a exploração dos recursos naturais, apenas arrefecerá”. 35

\footnotetext{
32 PEREIRA, Agostinho Oli Koppe. Responsabilidade civil por danos ao consumidor causados por defeitos dos produtos: a teoria da ação social e o direito do consumidor. Porto Alegre: Livraria do Advogado, 2003. p. 80 (grifo do autor).

${ }^{33}$ CORTEZ, Ana Tereza Caceres; ORTIGOZA, Sílvia Aparecida Guarnieri (Org.). Consumo sustentável: conflitos entre necessidade e desperdício. São Paulo: Unesp, 2007. p. 9.

${ }^{34}$ PORTILHO, Fátima. Sustentabilidade ambiental, consumo e cidadania. São Paulo: Cortez, 2005. p. 15.

${ }^{35}$ GIRON, Jerônimo et al. Direito, economia, capitalismo, consumo e meio ambiente, relaçốes. In: RECH, Adir Ubaldo; BUTZKE, Alindo; GULLO, Maria Carolina (Org.). Direito, economia e meio ambiente: olhares de diversos pesquisadores. Caxias do Sul, RS: Educs, 2012. p. 41.
} 


\subsection{CLIMA E 0 CONSUMO SUSTENTÁVEL}

Como mencionado, o aquecimento global somente se tornou um tema de preocupação mundial a partir da publicação do quarto relatório do IPCC, em 2007, o que inicialmente estabeleceu o homem como causador dos efeitos gravosos das mudanças do clima. A repercussão do tema logo foi se aproximando do universo dos consumidores, evoluindo da abordagem apocalíptica inicial (e dicotômica: a humanidade versus as mudanças do clima) para a de incentivo da açáo individual colaborativa com a mitigação dos efeitos climáticos. Pode-se afirmar, nesse contexto, que passa a ser de cada ser humano, como consumidor, a escolha (em havendo escolha) de atentar para o seu padrão de consumo, de modo que isso venha a significar maior ou menor responsabilização por parcela dos rumos do planeta.Clima e consumo passaram a se constituir como par temático, ou seja, as mudanças do clima passaram a ser um problema também da ordem do consumo, caracterizando uma confluência ou uma tentativa de confluir esses dois propósitos, consumo e ambiente, estabelecendo pontes explicativas entre o universo do consumo e os problemas ambientais. ${ }^{36}$

Essa aproximação - e sua força argumentativa - pode ser percebida nos discursos sobre consumo sustentável emitidos pelo poder público, a iniciativa privada e o terceiro setor (particularmente pelas entidades protetivas do cidadão-consumidor), analisados na sequência.

\subsubsection{0 poder público, o clima e o consumo sustentável}

No âmbito da ONU, a Organização para o Desenvolvimento Industrial (Unido) e o Programa de Meio Ambiente (Pnuma) definiram a conceituação de produção limpa no começo da década de 90, ainda que a preocupaçáo com a temática remonte à Conferência de Estocolmo, em 1972. Trata-se, em síntese, da incorporação da variável ambiental - essencialmente preventiva - aos processos,

${ }^{36}$ PAZ, Josi. O clima do consumo: a sociedade de consumidores no debate sobre a mudança climática. 2012. 559 p. Tese (Doutorado em Sociologia) - Universidade de Brasília, Brasília, 2012. p. 75, 471, 74. 
produtos e serviços, arrefecendo riscos ambientais e sanitários, o que exige inovação industrial. Deve-se promover, por exemplo, a redução do uso da água no processo produtivo ou, ainda, a prevenção e redução dos resíduos gerados na produção, significando, no limite, uma menor geração de GEE e, por consequência, a possibilidade de uma produçáo de baixo carbono, como se afirma costumeiramente. Endossam essa perspectiva o Processo de Marrakesh (iniciado em 2003, decorrente da instituição da "Agenda 21", documento da "Rio-92"), também no âmbito da ONU, e, mais tarde, o documento final da "Rio+20", que, em linhas gerais, convergem na promoção de um desenvolvimento sustentável a partir do incentivo de alternativas ambientalmente benéficas de produção e consumo.

Na problematização ambiental do consumo, o Brasil instituiu o consumo sustentável oficialmente como política pública em 2008 com o Plano de Ação para Produção e Consumo Sustentáveis, o PPCS, com sua última versão datada do final de 2011.

A existência do PPCS, que teve sua primeira fase encerrada em 2014, obedece justamente ao compromisso assumido pelo Brasil no Processo de Marrakesh em 2007. Sob a organização do Pnuma, esse documento é uma plataforma global que comunga as partes interessadas em trabalharem para a promoção e estabelecimento de padrōes de produção e consumo sustentáveis. Assim, nos termos do Processo de Marrakesh,

Produção Sustentável é a incorporação, ao longo de todo o ciclo de vida de bens $e$ serviços, das melhores alternativas possiveis para minimizar custos ambientais e sociais. Acredita-se que esta abordagem preventiva melhore a competitividade das empresas e reduza o risco para saúde humana e meio ambiente. Vista numa perspectiva planetária, a produção sustentável deve incorporar a noção de limites na oferta de recursos naturais e na capacidade do meio ambiente para absorver os impactos da ação humana. ${ }^{37}$

Por sua vez, consumo sustentável é

${ }^{37}$ MINISTÉRIO DO MEIO AMBIENTE. Plano de ação para produção e consumo sustentáveis. Brasília: MMA, 2011. p. 14. 
[...] o uso de bens e serviços que atendam às necessidades básicas, proporcionando uma melhor qualidade de vida, enquanto minimizam o uso dos recursos naturais e materiais tóxicos, a geração de resíduos e a emissão de poluentes durante todo ciclo de vida do produto ou do serviço, de modo que não se coloque em risco as necessidades das futuras geraçóes. ${ }^{38}$

A contribuição institucionalmente assumida pelo PPCS é a de promover alteraçóes verificáveis nos padróes de produção e consumo brasileiros, contemplando uma série de açóes participativas e comunicacionais, especialmente em relação ao uso responsável dos recursos naturais e à manutenção de uma economia de baixa emissão de carbono. Por essa razão, no enfrentamento de alguns dos efeitos colaterais do consumo, tem como eixos duas políticas nacionais em curso, a Política Nacional de Resíduos Sólidos, a PNRS, e a Política Nacional sobre Mudança do Clima, a PNMC. Compreende-se, assim, que junto do arcabouço normativo que orienta novas tendências dos padróes de produção e consumo, também são necessárias políticas públicas que intentem mudanças culturais e comportamentais em relação ao consumo. A sinergia entre as ações é justificada nos seguintes termos:

Enquanto o PNMC volta-se principalmente para as açóes governamentais e do setor produtivo, com foco na redução das emissóes de gases de efeito estufa resultantes do desmatamento e dos macros setores de energia e transportes, o PPCS enfatiza o papel do consumidor na demanda por produtos e serviços mais sustentáveis ao longo de toda cadeia produtiva, bem como na responsabilidade individual e coletiva dos cidadãos brasileiros. [...] Ao lado do PNMC, a PNRS compóe o arcabouço institucional para o PPCS, completando o tripé da sustentabilidade que fundamenta a política de governo [...] - desenvolvimento econômico, proteção ambiental e justiça social, aliados à qualidade de vida para todos. ${ }^{39}$

\footnotetext{
${ }^{38}$ MINISTÉRIO DO MEIO AMBIENTE. Plano de ação para produção e consumo sustentáveis. Brasília: MMA, 2011. p. 14.

${ }^{39}$ MINISTÉRIO DO MEIO AMBIENTE. Plano de ação para produção e consumo sustentáveis. Brasília: MMA, 2011. p. 20.
} 
Conforme observa Paz, instaura-se

[...] um contexto até então inédito no país: diretrizes que claramente colocam o consumo como objeto da política ambiental. Sob a tônica do compartilhamento de responsabilidades, tais políticas [PPCS, PNMC e PNRS] ponderam sobre um consumo que extrapola o gesto individual, ainda que o destaque como imagem paradigmática do seu argumento seja em torno do gesto individual de consumo. ${ }^{40}$

Como se observa, o Brasil, ao menos em sua produção legislativa recente, apresenta-se interessado em vivenciar uma economia de baixo carbono, no entendimento de que produção e consumo consubstanciam um processo interrelacionado, uma cadeia produtiva do consumo. Além disso, como vida e clima estão fundamentalmente relacionados, e, pelo prisma preponderante das análises, a economia depende sobremaneira do perfil climático e de sua estabilidade, é certo que "dano ambiental significa perda econômica” ${ }^{41}$

A PNRS foi a primeira legislação nacional a estabelecer a conceituação dos padrôes sustentáveis de produção e consumo (artigo 3º, inciso XIII), na consecução de um de seus princípios, o do desenvolvimento sustentável (artigo 6º, inciso IV). Com efeito, significa a adoçáo de práticas de minimização quantitativa e qualitativa de danos ambientais, como a opção por embalagens estritamente necessárias e o emprego de materiais menos contaminantes, respectivamente. Além disso, devese buscar o melhor aproveitamento dos bens envolvidos no processo produtivo, a partir da premissa de que o primeiro intento é não gerar resíduos (artigo $7^{\circ}$, inciso II). Diante disso, o consumidor já não pode mais ser entendido como um gerador passivo de resíduos, ao contrário, pois existindo o sistema de coleta seletiva ou sendo o produto consumido objeto de logística reversa, cabe ao consumidor um papel ativo em relação aos resíduos produzidos. Assim, “o que se pretende é transformar

${ }^{40}$ PAZ, Josi. O clima do consumo: a sociedade de consumidores no debate sobre a mudança climática. 2012. 559 p. Tese (Doutorado em Sociologia) - Universidade de Brasília, Brasília, 2012. p. 242.

${ }^{41}$ GILDING, Paul. A grande ruptura: como a crise climática vai acabar com o consumo e criar um novo mundo. Tradução Renato Aguiar. Rio de Janeiro: Apicuri, 2014. p. 53. 
um ciclo (de consumo) vicioso num ciclo (de consumo) virtuoso". ${ }^{42}$ Destaca-se, ainda, o papel do Estado como consumidor, que deve optar por produtos mais ambientalmente favoráveis (artigo 7o, inciso XI). A PNRS ficou conhecida por tratar do que se convencionou chamar de "responsabilidade pós-consumo".

Tecnicamente não é de responsabilidade que se trata, mas da imposiçáo de deveres jurídicos originários que pressupóem a existência de uma relação de consumo anterior. Deveres que têm por finalidade disciplinar especialmente a destinaçáo dos resíduos de produtos e serviços após o exaurimento de sua fruição pelo consumidor. ${ }^{43}$

Desse modo, em tese, cumpre ao setor econômico uma verdadeira varredura do ciclo de vida dos produtos e serviços que oferece, mapeando as fases da cadeia produtiva que geram impactos, bem como as possibilidades de prevençáo e economia de energia e recursos naturais. Cabe também ao integrante da cadeia econômica o dever de informar o consumidor sobre as características dos produtos e serviços ofertados. Fabricantes, importadores, distribuidores e comerciantes de produtos e serviços têm o dever preventivo de cuidado ambiental que se inicia com a concepção do produto, para além de determinados setores, considerados ambientalmente mais impactantes, que já cumprem limites e exigências previamente estipulados (como as licenças, por exemplo). Em igual sentido, salienta-se, sendo prioritário transformar os padróes de produção e consumo, as responsabilidades individuais unem-se às institucionais, corporativas e estatais. Desse modo, o desenvolvimento sustentável exige uma modernização estrutural do mercado com vistas à sustentabilidade ambiental.

E é exatamente o que propóe a PNMC a partir do enfoque climático, também alinhada ao desenvolvimento sustentável (artigo 30) e ao estímulo e apoio à manutenção e promoção de padróes sustentáveis de produção e consumo (artigo 5o, inciso XIII, alínea “b”).

42 GARCIA, Leonardo de Medeiros. Consumo sustentável: a proteção do meio ambiente no Código de Defesa do Consumidor. Salvador: JusPODIVM, 2016. p. 77-78.

${ }^{43}$ MIRAGEM, Bruno. Consumo sustentável e desenvolvimento: por uma agenda comum do direito do consumidor e do direito ambiental. Revista do Ministério Público do RS, Porto Alegre, n. 74, p. 229-244, p. 234, jul./dez. 2013. 
Foi como resultado do processo iniciado pelo IPCC, a propósito, que ocorreu a "Rio-92", que promoveu um processo decisório coletivo entre seus países-membros com vistas ao combate dos efeitos das mudanças do clima (temática de um de seus eixos). $\mathrm{Na}$ ocasião, em cenário propício - após o fim da guerra fria e diante de indicadores que expressavam a urgência ambiental - foi aprovada a Convenção-Quadro das Naçóes Unidas sobre Mudança do Clima (CQNUMC), em que o Brasil, na condição de país em desenvolvimento e não listado no Anexo 1 do documento, comprometeu-se de maneira voluntária a publicar periodicamente um inventário nacional de suas emissóes de GEE e colocar em prática políticas públicas que contemplassem medidas de mitigação das mudanças climáticas. Destaca-se, nesse sentido, que a CQNUMC foi o primeiro grande reconhecimento político e público para a questáo climática.

A função primordial da CQNUMC foi a de estabelecer os contornos das estratégias de combate aos efeitos das mudanças climáticas, sem fixar especificamente as respectivas regras, ou, em outras palavras, a de traçar linhas gerais a serem complementadas pelas resoluçôes posteriores das Conferências das Partes, as COPs, reunióes que passaram a ser realizadas de ano em ano.

A PNMC, ensaiada em ocasiōes anteriores, efetivamente nasceu de um compromisso assumido na COP-15, em 2009, realizada em Copenhague, na Dinamarca, pouco tempo após a problemática do clima, como visto, ter sido colocada na pauta mundial pelo IPCC em 2007 e, quase ato contínuo, ter sido aproximada do universo dos consumidores pelos setores sociais. Assim, a COP-15, embora em âmbito internacional tenha sido considerada decepcionante, sem um acordo global que estabelecesse metas de redução das emissóes de GEE, na perspectiva brasileira "em Copenhague o que importou foi a travessia, não o ponto de chegada" ${ }^{44} \mathrm{Com}$ a PNMC, considerada representante da "vanguarda legislativa do Direito Ambiental brasileiro", ${ }^{45}$ o Brasil "marcou uma crucial mudança da política climática domés-

${ }^{44}$ ABRANCHES, Sérgio. Copenhague: antes e depois. Rio de Janeiro: Civilizaçăo Brasileira, 2010. p. 279.

${ }^{45}$ SARLET, Ingo Wolfgang; FENSTERSEIFER, Tiago. Direito ambiental: introdução, fundamentos e teoria geral. São Paulo: Saraiva, 2014. p. 280. 
tica em direção a uma posição mais reformista”, ${ }^{46}$ sendo, aliás, o primeiro país em desenvolvimento a assumir oficialmente perante a comunidade internacional compromissos voluntários de redução das emissóes de GEE, de modo que "[...] a nova lei e as metas assumidas pelo país são passos de fundamental importância para a trajetória futura das suas políticas externa, econômica, energética, agrícola, florestal e climática”. ${ }^{47}$

Nessa esteira, a meta voluntária estabelecida pela PNMC - a de reduzir entre 36,1\% e 38,9\% as emissóes brasileiras de GEE projetadas até 2020 - e, por consequência, a consolidação brasileira de uma economia de baixo carbono estão vinculadas às açóes eleitas conjuntamente a partir de dois recortes estratégicos que, direta e indiretamente, abarcam toda a cadeia produtiva. $\mathrm{O}$ primeiro, de suporte setorial, determina os planos de mitigação e adaptaçáo às mudanças climáticas nas áreas energética, agropecuária, de saúde, transporte e mobilidade urbana, do desdobramento de matriz industrial, nas áreas de siderurgia, mineração, construção civil, química, de transformação, papel e celulose e de bens de consumo duráveis; o segundo, de critério regional, organiza os planos de ação para prevenção e controle do desmatamento dos biomas do Cerrado e o amazônico, objetivando, assim, a gestão daquela "que vem (ou vinha) até então sendo principal fonte emissora [de GEE] no país". ${ }^{48}$

O Brasil, a propósito, tem um perfil inteiramente singular de emissóes de GEE, visto que mais da metade delas provém de mudanças de uso do solo (desmatamento, queimadas, expansão agropecuária), enquanto nos países chamados desenvolvidos a principal fonte de emissão são os combustíveis fósseis. Bem mais da metade do desmatamento nos biomas amazônico e do Cerrado no Brasil ocorrem para a abertura de pastagens para os rebanhos. Há, portanto, uma nítida associação

${ }^{46}$ FRANCHINI, Matías; RIBEIRO, Thais Lemos; VIOLA, Eduardo. Sistema internacional de hegemonia conservadora: governança global e democracia na era da crise climática. São Paulo: Annablume, 2013. p. 322.

${ }^{47}$ FRANCHINI, Matías; RIBEIRO, Thais Lemos; VIOLA, Eduardo. Sistema internacional de hegemonia conservadora: governança global e democracia na era da crise climática. São Paulo: Annablume, 2013. p. 323.

${ }^{48}$ LAVRATTI, Paula; CAVEDON-CAPDEVILLE, Fernanda de Salles. Política Nacional sobre Mudança do Clima. In: LEITE, José Rubens Morato (Coord.). Manual de direito ambiental. São Paulo: Saraiva, 2015. p. 532. 
entre a pecuária bovina, por exemplo, e a emissáo de GEE, a partir de um ciclo que se inicia com a derrubada da floresta até a produção industrial da carne, uma vez que o país é o maior exportador de carne do mundo. Como descreve Paz, ${ }^{49}$

[...] embora ocorrendo numa floresta distante do shopping e do supermercado, o desmatamento estaria diretamente vinculado à "pegada ecológica” do consumo individual, em função da cadeia produtiva dos objetos: se não combatido, o desmatamento acabaria "sustentando" um consumo "não-sustentável”.

Ainda a título de exemplo, cita-se que as emissóes do setor energético apresentam contínuas tendências de crescimento ${ }^{50}$ e o incremento da frota automobilística é um dos grandes desafios brasileiros na garantia de mobilidade com redução de GEE. É por essa razão que, como se verá na sequência, o discurso do terceiro setor, aliado à manutenção da estabilidade climática, visa aos componentes de consumo mais emblemáticos para a realização de um consumo sustentável, como a intensa ingestão de carne e o desperdício de energia, por exemplo.

\subsubsection{A iniciativa privada, o clima e o consumo sustentável}

De acordo com Portilho, ${ }^{51}$ o setor empresarial não tardou "a adotar a imagem de 'amigo do verde'”, de modo que o desenvolvimento sustentável passou a ser tema e preocupaçáo na agenda corporativa. Hoje, seja pela vontade dos dirigentes ou pelo cuidado da imagem das empresas perante os consumidores, um número crescente de corporaçóes líderes setoriais globais têm buscado aderir a práticas mais sustentáveis e o discurso sobre consumo sustentável dentro do setor empresarial passou a ser corriqueiro.

${ }^{49}$ PAZ, Josi. O clima do consumo: a sociedade de consumidores no debate sobre a mudança climática. 2012. 559 p. Tese (Doutorado em Sociologia) - Universidade de Brasília, Brasília, 2012. p. 104.

${ }^{50}$ Cf. os Planos Decenais de Expansão de Energia do Brasil, revistos anualmente. Disponível em: <http:// www.epe.gov.br/pdee/forms/epeestudo.aspx>.

${ }^{51}$ PORTILHO, Fátima. Sustentabilidade ambiental, consumo e cidadania. São Paulo: Cortez, 2005. p. 112. 
A população brasileira, em expansão, aumenta suas demandas por novos produtos e serviços. Ela espera das empresas um padrão de eficácia que assegure preços competitivos e um alto grau de responsabilidade voltado para o desenvolvimento duradouro. As oportunidades para novos empreendimentos e para a consolidação de empresas estão nos mercados já estabelecidos, nas novas fronteiras de desenvolvimento e nos setores emergentes. Diante desse quadro, são as empresas com maior visão de futuro que podem fazer da sustentabilidade uma vantagem competitiva. Isso as tornará mais eficientes e fortalecerá o entorno do qual depende a sua perenidade. ${ }^{52}$

No que respeita às mudanças do clima, por exemplo, existe um rol de empresas que passaram a desenvolver produtos e serviços favoráveis ao clima. ${ }^{53}$ Vale relembrar que “embora os nomes 'fantasia' dos diversos produtos sejam diferentes [...], suas cadeias produtivas remontariam a um mesmo grupo de poucas e grandes corporaçóes transnacionais", ${ }^{4}$ de modo que a possibilidade de escolha, primeiro pressuposto da ação do consumidor, já se encontra previamente delimitada, ainda que ele talvez nem desconfie. De toda sorte, particularmente no Brasil, cita-se a existência desde 2009 da plataforma "Empresas pelo Clima", 55 cuja ação ocorre na articulação de lideranças empresariais para a gestão e redução de emissóes de GEE e, ainda, na divulgação de iniciativas desenvolvidas no meio corporativo para estimular uma economia de baixa emissão de carbono.

Embora não seja objeto de aprofundamento desta pesquisa, menciona-se que o consumo sustentável, por parte das empresas, está associado a produtos ou serviços informados como ambientalmente corretos, seja de modo publicitário direto ou indireto (como as certificaçóes).

\footnotetext{
${ }^{2}$ MARCOVITCH, Jacques. Para mudar o futuro: mudanças climáticas, políticas públicas e estratégias empresariais. São Paulo: Edusp, 2012. p. 159.

${ }^{53}$ Cf. disponível em: <http://unfccc.int/adaptation/workstreams/nairobi_work_programme/items/6547. php>.

${ }^{54}$ PAZ, Josi. O clima do consumo: a sociedade de consumidores no debate sobre a mudança climática. 2012. 559 p. Tese (Doutorado em Sociologia) - Universidade de Brasília, Brasília, 2012. p. 313.

${ }^{55}$ Cf. disponível em: <http://www.empresaspeloclima.com.br/>.
} 
Desde a perspectiva de ordenação do mercado de consumo [...], são de grande relevância as iniciativas que impóem deveres aos fornecedores, também atuem na promoçấo de comportamentos ambientalmente adequados. É o caso da diferenciação de produtos e serviços em face de processos produtivos ambientalmente adequados e certificados por selos ambientais, ou mesmo o dever de informar do fornecedor em relação a produtos que ofereçam riscos, mesmo que desconhecidos, simultaneamente ao consumidor e ao meio ambiente. ${ }^{56}$

A propósito, inexistindo os benefícios ambientais aludidos aos produtos ou serviços, ou seja, havendo uma "maquiagem verde" de produtos e serviços, existe a configuração de espécie de publicidade enganosa, nos termos do CDC (artigo 37, parágrafos $1^{\circ}$ e $3^{\circ}$ ).

\subsubsection{0 terceiro setor, o clima e o consumo sustentável}

Em que pesem seus perfis diferenciados, duas Organizaçóes Não Governamentais (ONGs) brasileiras são destacadamente ativas na promoção do consumo sustentável, o Instituto Brasileiro de Defesa do Consumidor, o Idec ${ }^{57}$ (cujo lema é ser "parceiro do consumidor") e o Instituto Akatu"s ("consumo consciente para um futuro sustentável”). Uma rápida passagem pelos sites de cada um já permite a observação de que o primeiro refere-se a um consumidor sustentável; o segundo, a um consumidor consciente. Constata-se, de saída, a inexistência de uma terminologia única entre essas ONGs, o que é observado de modo amplo perpassando todos os setores sociais. Como afirma Portilho:

\footnotetext{
${ }^{56}$ MIRAGEM, Bruno. Consumo sustentável e desenvolvimento: por uma agenda comum do direito do consumidor e do direito ambiental. Revista do Ministério Público do RS, Porto Alegre, n. 74, p. 229-244, p. 231, jul./dez. 2013.

${ }^{57}$ Cf. disponível em: <http://www.idec.org.br/>.

${ }^{58}$ Cf. disponível em: <http://www.akatu.org.br/>.
} 
A questão do impacto ambiental do consumo foi definida, inicialmente, nos limites da noção "consumo verde" e um pouco mais tarde concentrou-se no chamado "consumo sustentável”, além de expressões similares que contribuem mais para confundir do que para enriquecer a discussão, tais como "consumo ético", "consumo responsável" e "consumo consciente". 59

No discurso do setor público, baseado no Processo de Marrakesh, fala-se em consumo sustentável, ou seja, dar preferência, no ato da compra, a um produto fabricado de maneira sustentável. No discurso da iniciativa privada, regra geral, tanto os termos quanto os sentidos sáo variáveis, ${ }^{60}$ assim como no caso dos dois exemplos ilustrativos trazidos do terceiro setor.

Contudo, a perspectiva sobre o que vem a ser consumo é mais ampla no discurso do Idec do que no discurso do Akatu. Para o Idec, consumo sustentável compreende o processo de fabricação de produtos, o uso cotidiano e o descarte dos mesmos. Já para o Akatu, embora preocupações relacionadas com o modo de descarte também estejam presentes, é notória a ênfase atribuída ao consumo sustentável como um sinônimo de compra consciente. ${ }^{61}$

De todo modo, apesar das diferentes expressóes utilizadas, pode-se "identificar pelo menos três elementos comuns às diversas definições de consumo sustentável: 1) satisfação de necessidades humanas; 2) preocupação com as futuras geraçóes e 3) preocupação com a distribuição social". ${ }^{62}$

${ }^{59}$ PORTILHO, Fátima. Sustentabilidade ambiental, consumo e cidadania. São Paulo: Cortez, 2005. p. 110.

${ }^{60}$ CORDEIRO, Itamar José Dias e. Consumo sustentável no Brasil: reflexões sobre os discursos do poder público, da iniciativa privada e do terceiro setor. 2012. 144 f. Dissertação (Mestrado em Desenvolvimento e Meio Ambiente) - Universidade Federal de Pernambuco, Recife, 2012, p. 94-102.

${ }^{61}$ CORDEIRO, Itamar José Dias e. Consumo sustentável no Brasil: reflexões sobre os discursos do poder público, da iniciativa privada e do terceiro setor. 2012. 144 f. Dissertaçấo (Mestrado em Desenvolvimento e Meio Ambiente) - Universidade Federal de Pernambuco, Recife, 2012, p. 116 (grifo do autor).

${ }^{62}$ PORTILHO, Fátima. Sustentabilidade ambiental, consumo e cidadania. São Paulo: Cortez, 2005. p. 137. 
Posto isso, exemplificando o modo como o "consumo é situado no debate sobre a questão do clima como parâmetro e possibilidade de intervenção", ${ }^{63} \mathrm{em}$ 2008 o Idec, uma associação de consumidores, em parceria com o Instituto para o Desenvolvimento, Meio Ambiente e Paz (ONG Vitae Civilis), lançou a campanha nacional "Mude o consumo para não mudar o clima", relacionando os hábitos individuais de consumo - consumo de carne, energia elétrica, transporte e descarte de resíduos, por exemplo - com as mudanças do clima. Desde então, a temática é recorrente em suas publicaçôes. Mantém, ainda, um site específico nomeado "Clima e consumo", "64 a partir do qual é possível calcular o total de emissôes de GEE com base em uma minuciosa descrição do consumo cotidiano: "a calculadora de emissóes é uma ferramenta de reflexão sobre o quanto esse consumo equivale em emissão de gases de efeito estufa e, ao mesmo tempo, dá dicas de como reduzi-la”, explica o site. Apenas a título de exemplo, segundo a calculadora do Idec, uma hipotética pessoa que more sozinha em Curitiba, no Paraná, acumula 445 quilos de lixo anualmente. Ainda, ao não utilizar transporte coletivo e nem avião por um ano, apenas o seu automóvel abastecido com gasolina (com gasto mensal de R \$ 200,00), somado aos $R$ \$100,00 de consumo mensal de eletricidade, mais $R$ \$ 50,00 mensais de gás liquefeito de petróleo (GLP), emite 6.412 quilos de $\mathrm{CO}_{2}$ ao ano, o similar a ter ficado 87 dias parada em um congestionamento com o carro ligado.

Durante todo o ano de 2016, o Instituto Akatu, oriundo do setor empresarial paulista, promove a campanha "Não deixe o \#CLIMA MUITO LOKO", com publicaçôes esparsas e em capítulos, na afirmação de que "suas escolhas de consumo podem ajudar a frear as mudanças climáticas". Note-se que o slogan da campanha é também uma expressão-chave, uma hashtag, utilizada para categorizar conteúdos nas redes sociais computacionais. Assim como faz o Idec, as orientaçóes do Akatu miram, em apanhado, o consumo de carne, o regular uso dos automóveis e o desperdício de energia. De acordo com o Instituto:

${ }^{63}$ PAZ, Josi. O clima do consumo: a sociedade de consumidores no debate sobre a mudança climática. 2012. 559 p. Tese (Doutorado em Sociologia) - Universidade de Brasília, Brasília, 2012. p. 70.

${ }^{64}$ Cf. disponível em <http://www.idec.org.br/climaeconsumo/>. 
Cada indivíduo pode ser protagonista nessa história. Além do fundamental papel do poder público, atitudes individuais fazem toda a diferença na redução das emissốes de gases de efeito estufa. A maior parte das causas e consequências da mudança do clima está diretamente ligada a necessidades e hábitos cotidianos. ${ }^{65}$

Verifica-se, assim, como as temáticas que envolvem clima e consumo estão conectadas nos principais discursos sociais brasileiros, embutidas em toda a "macrorrelação ambiental de consumo". ${ }^{66}$

\section{CONSUMO SUSTENTÁVEL}

A defesa do consumidor e do meio ambiente no Brasil é originária de um mesmo contexto histórico, da relevância de novos interesses jurídicos exigentes de proteção estatal e, ao mesmo tempo, com amplas e diretas repercussóes coletivas.

A Constituição Brasileira de 1988 assegura a defesa do consumidor entre os seus direitos fundamentais (artigo $5^{\circ}$, inciso XXXII), além de princípio conformador da ordem econômica, de acordo com o artigo 170, inciso V. O direito ao meio ambiente ecologicamente equilibrado, por sua vez, materialmente fundamental (pois sinônimo da manutenção de todas as formas de vida), em capítulo próprio, está previsto no artigo 225 da Constituição, com a defesa do ambiente constituindo também um dos princípios da ordem econômica (artigo 170, inciso VI). Nesse sentido, a regulação do desenvolvimento econômico no Brasil implica tanto a observância dos direitos do consumidor quanto o cuidado com o ambiente (havendo imposição de normas para a atividade econômica conforme o impacto ambiental dos produtos e serviços gerados).

${ }^{65}$ INSTITUTO AKATU. Para termos água em nossas torneiras, precisamos combater as mudanças climáticas. 2016. Disponível em: <http://www.akatu.org.br/Temas/Mudancas-Climaticas/Posts/Para-termos-agua-em-nossas-torneiras-precisamos-ajudar-a-combater-as-Mudancas-Climaticas $>$. Acesso em: 5 jul. 2016.

${ }^{66}$ MORAES, Paulo Valério Dal Pai. Macrorrelação ambiental de consumo: responsabilidade pós-consumo ou relação coletiva de consumo? Porto Alegre: Livraria do Advogado, 2013. 
O Código de Defesa do Consumidor (CDC), norma de ordem pública e interesse social, introduziu a Política Nacional de Relaçôes de Consumo e disciplinou, entre outros, os direitos básicos do consumidor (artigo $6^{\circ}$ ), como a proteção da vida, da saúde e da segurança. Insere-se, a propósito, no contexto da tutela dos direitos difusos e coletivos, posto que não raro a ilicitude nas relaçóes consumeristas afeta toda a coletividade. O Direito Ambiental, por sua vez, é um direito difuso. Ambos - direito das relaçôes de consumo e Direito Ambiental - são considerados de terceira geração ou dimensão, vinculados à solidariedade, de características metaindividuais.

Quando da sua confecção, os valores ambientais incluídos no CDC foram relacionados apenas ao conceito de abusividade (de publicidade abusiva, no artigo 37, parágrafo $2^{\circ}$, e de cláusulas contratuais abusivas, no artigo 51, inciso XIV). O CDC, todavia, é sobretudo uma lei principiológica, de modo que seu conteúdo acompanha as novas exigências de proteção do consumidor, incorporando interpretaçôes extensivas em todos os aspectos do consumo e, por consequência, da produção. Desse modo, embora o CDC náo trate de consumo sustentável, a sua prática não está desprovida de lastro legal. Além disso, o Plano Nacional de Consumo e Cidadania (instituído pelo Decreto n. 7.963/2013) prevê a promoção do acesso a padrôes de produção e consumo sustentáveis (artigo 3º, inciso V), evidenciando a sua incorporação pelo direito das relações de consumo. Nada obstante, recentemente foi instituída a Política de Educaçáo para o Consumo Sustentável (Lei n. 13.186/2015), com o objetivo de estimular a adoção de práticas de consumo e de técnicas de produção ecologicamente sustentáveis, em que "entende-se por consumo sustentável o uso dos recursos naturais de forma a proporcionar qualidade de vida para a geraçáo presente sem comprometer as necessidades das geraçôes futuras" (artigo 1º, parágrafo único). Ao analisar a relevância da Lei n. 13.186, Garcia pondera que 
[...] não somente a informação é importante. Antes disso, porém, é necessária a educaçáo ambiental, promovendo nova mentalidade na sociedade sobre a preservação ambiental. Educar primeiro e informar depois. Somente o consumidor consciente poderá fazer uso correto e eficiente das informaçóes ambientais. ${ }^{67}$

De toda sorte, em razão da conjugação dos preceitos constitucionais relativos à proteçáo do consumidor e do ambiente, impóe-se o reconhecimento do acesso ao consumo de forma coerente com o desenvolvimento sustentável, ou seja, de modo ordenado com a defesa ambiental para as presentes e futuras geraçóes, de acordo com a previsáo constitucional. Em igual sentido, a instituição de um consumo sustentável, como demonstrado, encontra lastro nas normas de natureza infraconstitucional, particularmente as referentes à defesa do consumidor e do meio ambiente. Em expressão direta e a título exemplificativo, o uso dos recursos ambientais utilizado na Política Nacional do Meio Ambiente (Lei n. 6.938/1981), "num vocabulário flexível e mais próximo da nossa preocupação, quer dizer consumo". ${ }^{68}$

Desse modo, a proteção do consumidor e do meio ambiente em razão da sustentabilidade ambiental do consumo ocorre por meio da interpretação dos princípios e regras estabelecidos pelo CDC de forma integrada com aqueles basilares do Direito Ambiental e legislação correlata, existindo assim uma transversalidade do ambiente sobre as relaçóes de consumo. Dito de outro modo, é no diálogo das fontes consumeristas e ambientais, objetivando o mais amplo nível protetivo, humano e ambiental, que se insere o consumo sustentável, “com nítida pretensão política e transformadora". ${ }^{69}$

No limite, o consumo sustentável tutela a vida e, em seu aspecto contextualizado, a vulnerabilidade em sentido lato.

${ }^{67}$ GARCIA, Leonardo de Medeiros. Consumo sustentável: a proteção do meio ambiente no Código de Defesa do Consumidor. Salvador: JusPODIVM, 2016. p. 152.

${ }^{68}$ MILARÉ, Édis. Direito do ambiente. 6. ed. São Paulo: Revista dos Tribunais, 2009. p. 89.

${ }^{69}$ PORTILHO, Fátima. Sustentabilidade ambiental, consumo e cidadania. São Paulo: Cortez, 2005. p. 134. 
A degradação ambiental é gerada pelo homem e - é inegável - põe em risco a continuidade da sua própria vida. Assim, como consequência de fatores econômicos - e das mazelas sociais, também derivadas ou agravadas por um modelo produtivo que vigora há 300 anos -, a degradação ambiental viola não só direitos específicos do indivíduo, como afeta principalmente a condicionante primária para a realização destes e de quaisquer outros direitos: a vida. ${ }^{70}$

Do mesmo modo,

[...] um vínculo indissociável entre o direito à sadia qualidade de vida e a proteçáo e promoção do bem-estar do consumidor. $\mathrm{O}$ direito à saúde e à vida do consumidor compreende a manutenção e promoção de sua qualidade de vida, o que, por conseguinte, depende em boa medida da preservação do meio ambiente. ${ }^{71}$

A capacitação do consumidor acerca da relação entre consumo e ambiente envolve o exercício de pelo menos três direitos fundamentais: o do direito ao meio ambiente ecologicamente equilibrado como pré-requisito para a existência de todas as formas de vida, incluindo a humana; o direito à informação, em que sejam contempladas as incertezas inerentes aos produtos, por exemplo, e o direito à educação como possibilidade de escolha refletida. Isso torna o consumidor, independentemente da adjetivação que a ele se dê, um ator consciente, responsável, solidário e sustentável no universo de consumidores, em um propósito de cooperação social.

Supostamente, quanto mais se reveste de globalidade o problema ambiental, mais difícil é demonstrar ao consumidor o nexo entre o gesto individual e sua responsabilidade no processo. É nesse sentido que se busca elucidar a convergência entre o ato de consumir e o cuidado com o ambiente. A informação, nesse contexto, para além de instrumento de proteção do consumidor, passa a influenciá-lo em suas decisóes, principalmente quando conhecido todo o ciclo de vida do produto.

${ }^{70}$ ROSS, Jurandyr Sanches (Org.). Geografia do Brasil. São Paulo: Edusp, 2014. p. 83.

${ }^{71}$ MIRAGEM, Bruno. Consumo sustentável e desenvolvimento: por uma agenda comum do direito do consumidor e do direito ambiental. Revista do Ministério Público do RS, Porto Alegre, n. 74, p. 229-244, p. 234, jul./dez. 2013. 
Um dos caminhos para que os consumidores se tornem mais responsáveis em relação ao meio ambiente seria fornecer informações sobre as conexôes entre suas atitudes, as opçóes como consumidores e a degradaçáo ambiental. Geralmente, os consumidores são mal informados sobre as conseqüências, para o meio ambiente, de suas escolhas de consumo e de estilos de vida. Entretanto, a fim de alcançar o consumo sustentável [...], os consumidores precisarão mais do que informaçóes. Será preciso, igualmente, uma mudança nas atitudes sociais e culturais, de modo que a liberdade pessoal de desfrutar de benefícios materiais aqui e agora seja contrabalanceada por um sentimento de responsabilidade compartilhado, a fim de promover o bem-estar de toda a humanidade, incluindo o das gerações futuras. ${ }^{72}$

Para que o consumidor escolha, contudo, é preciso que conheça o produto ou serviço, que seja informado sobre eles e, nesse sentido, os aspectos ecológicos dos produtos e serviços são dados essenciais. $\mathrm{O}$ artigo $6^{\circ}$, incisos II e III do CDC resguardam justamente a liberdade de escolha do consumidor, isto é, a sua capacidade de fazer uma opção informada e consciente no ato da aquisição de um produto ou contratação de um serviço. $\mathrm{O}$ direito à informação tem como contrapartida o dever de informar do fornecedor, sendo ilícita a sua omissão.

Ao mesmo passo, a concepção de vulnerabilidade une a tutela dos direitos do consumidor e a defesa do ambiente. $\mathrm{O}$ consumidor, de seu lado, apartado do controle da produção, é reconhecido como vulnerável diante da cadeia econômica, ou seja, em razáo de sua defasagem informacional em relação aos produtos e serviços (suas características, componentes e riscos), situação que o faz ocupar uma posição de desigualdade material nas relaçóes de consumo. Por sua vez, em virtude do impacto ambiental do consumo, existe a vulnerabilidade das geraçóes futuras. Integrar essas duas esferas protetivas - consumidor e ambiente - estabelecendo direitos e obrigaçóes correlacionados, é certamente um dos grandes desafios desta época, que, como saldo, acarretaria a verdadeira prática de um consumo sustentável. Como afirma Miragem,

${ }^{72}$ CORTEZ, Ana Tereza Caceres; ORTIGOZA, Sílvia Aparecida Guarnieri (Org.). Consumo sustentável: conflitos entre necessidade e desperdício. São Paulo: Unesp, 2007. p. 12. 
[...] um dos aspectos de mais difícil interpretação in concreto [...] é o equilíbrio do interesse entre as presentes e futuras geraçóes, ou seja, entre interesses atuais e futuros, seja no âmbito do direito ambiental, seja no direito do consumidor. ${ }^{73}$

A reflexão sobre o consumo sustentável remonta a dois documentos oficiais internacionais, a "Agenda 21", produzida na "Rio-92", e as Diretrizes da ONU para a Proteção dos Consumidores. De acordo com a "Agenda 21", o ambiente mundialmente deteriorado, entre outras causas, deve-se aos padróes insustentáveis de consumo e produção, agravantes da pobreza e demais desequilíbrios. Além do diagnóstico até então inédito, o documento impôs aos governos uma pauta de atitudes na consecução de um consumo sustentável. Por seu turno, as Diretrizes da ONU [...], em enxerto no texto original, passaram a estabelecer direitos básicos para toda a sociedade mundial de consumidores. Sobre o consumo sustentável, afirma o documento:

A responsabilidade do consumo sustentável é compartilhada entre os membros e as organizações da sociedade, incluídos os consumidores informados, governos, empresas, organizaçóes laborais, consumeristas e ambientais [...]. Os consumidores informados desempenham uma função essencial na promoção do consumo que é sustentável do ponto de vista ambiental, social e econômico, inclusive pelas repercussóes de suas escolhas ante os produtores. Os governos devem promover o desenvolvimento, a implementação e a integração de políticas públicas para o consumo sustentável, formuladas a partir de consultas aos grupos interessados. As empresas têm responsabilidade na promoção do consumo sustentável por meio do design, produção e distribuição de bens e serviços. As organizações de defesa ambiental e de consumidores têm a responsabilidade de promover a participação e o debate públicos a respeito do consumo sustentável, trabalhando conjuntamente com empresas e governo. ${ }^{74}$

${ }^{73}$ MIRAGEM, Bruno. Consumo sustentável e desenvolvimento: por uma agenda comum do direito do consumidor e do direito ambiental. Revista do Ministério Público do RS, Porto Alegre, n. 74, p. 229-244, p. 230, jul./dez. 2013.

${ }^{74}$ UNITED NATIONS. United Nations guidelines on consumer protection: as expanded in 1999. Genebra: Unctad, 2011. p. 11. Disponível em: <http://unctad.org/en/Docs/poditcclpm21.en.pdf >. Acesso em: 12 jul. 2016 (tradução nossa). 
O consumo sustentável se justifica no princípio da sustentabilidade, como princípio implícito do direito do consumidor decorrente da proteçáo da dignidade da pessoa humana e da cidadania. Para que o objetivo da Política Nacional de Relações de Consumo possa ser alcançado é necessário que todos os agentes econômicos participantes contribuam para tanto. Desse modo, o consumo sustentável vem politizando a vida e, como resultado dessa articulaçáo, novos modos de ser tornam-se emergentes. ${ }^{75}$

Verifica-se, assim, que a proposta de um consumo sustentável, ainda que no limite de suas açôes, estabelece deveres comuns de consumidores e fornecedores, rompendo com a oposição entre direitos de uns e obrigaçóes de outros. Reconhece-se, portanto, que a maneira de consumir praticada pelo universo de consumidores está alicerçada em um modelo estratégico e insustentável de produção e oferta de produtos. Nessa dinâmica, todos têm responsabilidade ambiental e, por isso, devem cooperar para a preservaçáo do ambiente presente, vinculado ao futuro.

O consumo consciente tem efeitos imediatos na economia e no meio ambiente, como também surte conseqüências para as futuras geraçóes, de modo que se preserva o ambiente em que se vive para se ter qualidade de vida presente e a manutenção desta a longo prazo, saneando-se também o próprio mercado. ${ }^{76}$

O papel do consumidor atualmente deixa de ser o de um agente passivo na cadeia econômica, de modo que passa a ser convocado a colaborar mediante a escolha sustentável dos produtos e serviços que adquire. O consumo sustentável exige, portanto, uma responsabilidade coletiva e compartilhada. Instaura-se, assim, uma agenda comum do Direito Ambiental e do consumidor: "trata-se de consumir melhor, nos padróes tecnicamente definidos, juridicamente assegurados e ambientalmente corretos". ${ }^{77}$

75 TAVARES, Fred; IRVING, Marta de Azevedo. Natureza S.A.: o consumo verde na era do ecopoder. São Carlos, SP: RiMa, 2009, p. 223 (grifo do autor).

${ }^{76}$ EFING, Antônio Carlos. Fundamentos do direito das relaçóes de consumo: consumo e sustentabilidade. 3. ed. Curitiba: Juruá, 2011. p. 126.

${ }^{77}$ MIRAGEM, Bruno. Consumo sustentável e desenvolvimento: por uma agenda comum do direito do consumidor e do direito ambiental. Revista do Ministério Público do RS, Porto Alegre, n. 74, p. 229-244, p. 243, jul./dez. 2013. 
O consumo sustentável pode ser entendido como o papel político do consumidor, mas, para tanto, este deve superar a conduta da mera escolha por produtos de apelo ecológico, executando um olhar menos acostumado para o consumo, passando da sustentabilidade para a responsabilidade no ato de comprar, o que envolveria a capacidade crítica de contextualizar a produçáo e o consumo, pois, espera-se, "é a demanda do consumidor, através de suas escolhas de consumo, que vai mudar o sistema produtivo". ${ }^{78}$

\subsection{A AMBIVALENTE CONFLUÊNCIA DO CONSUMO SUSTENTÁVEL E AS MUDANÇAS DO CLIMA}

Como se buscou delinear até aqui, decorre de uma compreensão integrada da sustentabilidade a urgência de se praticar um consumo sustentável. Esse modelo de sustentabilidade, sob o prisma da racionalidade econômica, pode ser entendido como um obstáculo, ${ }^{79}$ mas, em análise ampla, trata-se da possibilidade de manutenção da vida no planeta. Assim, uma sustentabilidade ampla vai exigir que o processo de produção e de consumo (e o mercado) sejam reformulados. Apartir do argumento de autoridade do IPCC, determinante do estado da arte das mudanças do clima, atribuiu-se à ação humana as causas do aquecimento climático global. A partir de então esse mote serviu de reforço discursivo do consumo sustentável, reiterado pelo poder público a partir do PPCS, que cooptou a PNMC e a PNRS, da iniciativa privada e do terceiro setor, exemplificado nesta pesquisa pelas ONGs Instituto Akatu e Idec.

Com amplo lastro jurídico, o consumo sustentável convoca o consumidor a repensar as repercussóes do ato de consumir, pois quanto maior for o consumo, maior será a produção e a geração de resíduos e, por consequência, as emissôes de GEE. O consumo sustentável seria, portanto, um espaço de equilíbrio entre a satisfação e a sustentabilidade.

${ }^{78}$ PORTILHO, Fátima. Sustentabilidade ambiental, consumo e cidadania. São Paulo: Cortez, 2005. p. 58.

79 VEIGA, José Eli da. "Não é que os empresários vejam a sustentabilidade como obstáculo; ela é mesmo um obstáculo”. In: ARNT, Ricardo (Org.). O que os economistas pensam sobre sustentabilidade. São Paulo: 34, 2010. p. 149. 
O discurso que atrela clima e consumo sustentável, contudo, pode ser, por vezes, ambivalente. Como descreve Paz: ${ }^{80}$

O mesmo consumo associado às causas da alteraçáo do clima - em funçáo do acúmulo de resíduos sólidos e do desmatamento, entre outros, que favoreceria a emissão de gases de efeito estufa - foi se colocando com mais evidência como a possibilidade do combate a essa realidade empírica: o consumo seria a chaga abordada como bálsamo.

Em outros termos, embora pareça mera reiteração do que é aparentemente nítido, cabe trazer a lume que é a existência de uma crise ecológica (na qual as mudanças do clima representam um dos seus diagnósticos) que suscita a proposta de um desenvolvimento sustentável e, a partir dele, de novos padróes de produção e consumo - assim, tratados em conjunto - também sustentáveis. A partir, no entanto, da síntese discursiva dos agentes verificados, colabora com a questão climática o consumidor que escolher produtos ou serviços de procedência ambientalmente favorável. Assim:

A hierarquização do consumo e do consumidor - "amigo" e "inimigo" do meio ambiente - criaria oportunidades de novas ou atualizadas promessas mercadológicas, que se materializariam em embalagens, nomes, rótulos, produtos, segmentos, oportunidades de revitalizar imagens corporativas sob o signo ecológico. ${ }^{81}$

Há, portanto, uma distinção entre a aquisição de um produto produzido de forma sustentável e o consumo sustentável, embora quase sempre essa diferenciação não seja explicitada e os atos sejam abordados como sinônimos. A produção sustentável, nesse sentido, pode tão somente reforçar a oportunidade do consumo. Talvez um consumo verdadeiramente sustentável e informado, careça, no limite, também da redução das taxas de consumo. Mais que isso, signifique profunda reflexão e esforço por parte do consumidor. Um contexto que deveria ser mais bem problematizado.

${ }^{80}$ PAZ, Josi. O clima do consumo: a sociedade de consumidores no debate sobre a mudança climática. 2012. 559 p. Tese (Doutorado em Sociologia) - Universidade de Brasília, Brasília, 2012, p. 537.

${ }^{81}$ PAZ, Josi. O clima do consumo: a sociedade de consumidores no debate sobre a mudança climática. 2012. 559 p. Tese (Doutorado em Sociologia) - Universidade de Brasília, Brasília, 2012, p. 538. 
Em pesquisa de 2012, Cordeiro analisou os discursos do poder público, da iniciativa privada e do terceiro setor acerca do consumo sustentável. Concluiu, em suma, que

[...] o propósito dos discursos analisados não é outro senão o de "esverdear" o processo produtivo de modo que as taxas de consumo não sejam afetadas. Assim, pode-se dizer que os discursos preocupam-se fundamentalmente com uma "sustentabilidade dos padrōes de consumo" e não com um consumo sustentável. ${ }^{82}$

No caso da relação entre mudanças do clima e consumo, o consumo sustentável vale-se de um paradoxo: "a noção de uma humanidade 'consumidora', como chaga do planeta, e o gesto individual de consumo como cura" ${ }^{83}$ Desse modo, o consumo sustentável praticado como consumo de produtos e serviços resultantes de práticas sustentáveis e, ao mesmo tempo, vinculado à salvaguarda da manutenção do sistema climático, torna nebuloso o espaço em que se poderia construir e debater um verdadeiro consumo sustentável. De outro modo, o consumo sustentável, proposta de superação do consumo verde, acaba por reforçá-lo, prolongando a crise ecológica estabelecida.

Enquanto o discurso do consumo sustentável permanecer como discurso do consumo da produçáo sustentável, uma sustentabilidade do consumo não será efetivamente possível. O que [se] nota, portanto, é uma intencionalidade, melhor dizendo: uma pseudo-irracionalidade dos discursos. Isto porque, embora pareçam não fazer sentido (uma vez que não conduzem a um efetivo consumo sustentável), na realidade atendem perfeitamente ao propósito para o qual foram criados: domesticar o consumidor. ${ }^{84}$

${ }^{82}$ CORDEIRO, Itamar José Dias e. Consumo sustentável no Brasil: reflexões sobre os discursos do poder público, da iniciativa privada e do terceiro setor. 2012. 144 f. Dissertação (Mestrado em Desenvolvimento e Meio Ambiente) - Universidade Federal de Pernambuco, Recife, 2012, p. 119 (grifo do autor).

${ }^{83}$ PAZ, Josi. O clima do consumo: a sociedade de consumidores no debate sobre a mudança climática. 2012. 559 p. Tese (Doutorado em Sociologia) - Universidade de Brasília, Brasília, 2012, p. 23.

${ }^{84}$ CORDEIRO, Itamar José Dias e. Consumo sustentável no Brasil: reflexōes sobre os discursos do poder público, da iniciativa privada e do terceiro setor. 2012. 144 f. Dissertaçâoo (Mestrado em Desenvolvimento e Meio Ambiente) - Universidade Federal de Pernambuco, Recife, 2012, p. 128 (grifo do autor). 
A par disso, o consumo sustentável é um universo de atitudes e práticas em plena construção. Se em alguma (ou elevada) medida está impregnado de formulaçóes anteriormente em curso e apenas reapresentadas, por outro lado é importante que se vá mais a fundo em sua significação para que, assim, possa ser preenchido de um discurso e, principalmente, uma prática com sinais inversos, claramente associados a uma sustentabilidade ampla.

\section{CONSIDERAÇÕES FINAIS}

Há pouca dúvida a respeito de que a atual sociedade de consumo está colaborando para a degradação ambiental, seja pelo abuso que faz dos recursos naturais ou pela excessiva produção de resíduos. A crise ecológica é multifacetada, e o desequilíbrio climático mundial é apenas mais um de seus aspectos.

Por essa razão, propugna-se por um consumo que seja verdadeiramente sustentável, para além da mera aquisição de produtos sustentavelmente produzidos, ainda que vinculados a condutas ambientais favoráveis. Enquanto suscitado em caráter simbólico, o consumo sustentável, já de saída, precisa ser reinventado.

Atrelado a uma perspectiva ampla de sustentabilidade, todavia, o consumo sustentável, como tentativa - inclusive jurídica - de manutenção ambiental com vistas ao futuro, pode ser ferramenta de grande impacto social, a ressignificar a cadeia produtiva e o gesto particular do consumo. Questiona-se, por derradeiro, se não será, em um futuro bastante próximo, uma adaptação contingencial diante da insustentabilidade geral assistida.

\section{REFERÊNCIAS}

ABRANCHES, Sérgio. Copenhague: antes e depois. Rio de Janeiro: Civilização Brasileira, 2010.

ALIER, Joan Martínez. O ecologismo dos pobres. São Paulo: Contexto, 2007.

ARNT, Ricardo (Org.). O que os economistas pensam sobre sustentabilidade. São Paulo: 34, 2010. 
AZEVEDO, Ana Lucia. Novos tempos: os homens que enfrentavam um furacão, o rapaz que surfava nuvens e outras histórias de tempestades no Brasil. Rio de Janeiro: Zahar, 2012. BAUDRILLARD, Jean. A sociedade de consumo. 2. ed. Lisboa: Edições 70, 2010.

BOFF, Leonardo. Sustentabilidade: o que é - o que não é. 2. ed. Petrópolis, RJ: Vozes, 2013. . A grande transformação: na economia, na política, na economia. Petrópolis, RJ: Vozes, 2014.

BRASIL. Constituição da República Federativa do Brasil de 1988. Diário Oficial da União, 5 de outubro de 1988, Brasília, 1988. . Lei n. 8.078. Diário Oficial da União, 11 de setembro de 1990, Brasília, 1990. . Lei n. 12.187. Diário Oficial da União, 29 de dezembro de 2009, Brasília, 2009. . Lei n. 12.305. Diário Oficial da Uniāo, 2 de agosto de 2010, Brasília, 2010. . Lei n. 13.186. Diário Oficial da União, 11 de novembro de 2015, Brasília, 2015. COMISSÃO MUNDIAL SOBRE MEIO AMBIENTE E DESENVOLVIMENTO. Nosso futuro comum. Rio de Janeiro: FGV, 1988.

CORDEIRO, Itamar José Dias e. Consumo sustentável no Brasil: reflexões sobre os discursos do poder público, da iniciativa privada e do terceiro setor. 2012. $144 \mathrm{f}$. Dissertação (Mestrado em Desenvolvimento e Meio Ambiente) - Universidade Federal de Pernambuco, Recife, 2012. CORTEZ, Ana Tereza Caceres; ORTIGOZA, Sílvia Aparecida Guarnieri (Org.). Consumo sustentável: conflitos entre necessidade e desperdício. São Paulo: Unesp, 2007.

DIAS, Genebaldo Freire. Mudança climática e você: cenários, desafio, governança, oportunidades, cinismos e maluquices. São Paulo: Gaia, 2014.

DIAS, Reinaldo. Sustentabilidade: origem e fundamentos; educação e governança global; modelo de desenvolvimento. São Paulo: Atlas, 2015.

EFING, Antônio Carlos. Fundamentos do direito das relaçôes de consumo: consumo e sustentabilidade. 3. ed. Curitiba: Juruá, 2011.

FERREIRA, Jorge Borges. Meio Ambiente. In: MOTTA, Márcia (Org.). Dicionário da terra. 2. ed. Rio de Janeiro: Civilização Brasileira, 2010. p. 295.

FRANCHINI, Matías; RIBEIRO, Thais Lemos; VIOLA, Eduardo. Sistema internacional de hegemonia conservadora: governança global e democracia na era da crise climática. São Paulo: Annablume, 2013.

FREITAS, Juarez. Sustentabilidade: direito ao futuro. 2. ed. Belo Horizonte: Fórum, 2012. 
GARCIA, Leonardo de Medeiros. Consumo sustentável: a proteção do meio ambiente no Código de Defesa do Consumidor. Salvador: JusPODIVM, 2016.

GIDDENS, Anthony. A politica da mudança climática. Tradução Vera Ribeiro. Rio de Janeiro: Jorge Zahar, 2010.

GILDING, Paul. A grande ruptura: como a crise climática vai acabar com o consumo e criar um novo mundo. Tradução Renato Aguiar. Rio de Janeiro: Apicuri, 2014.

GIRON, Jerônimo et al. Direito, economia, capitalismo, consumo e meio ambiente, relações. In: RECH, Adir Ubaldo; BUTZKE, Alindo; GULLO, Maria Carolina (Org.). Direito, economia e meio ambiente: olhares de diversos pesquisadores. Caxias do Sul, RS: Educs, 2012. p. 41.

GORE, Al. Nossa escolha: um plano para solucionar a crise climática. Tradução Fabiana de Carvalho, Maria Augusta Tedesco e Otávio Albuquerque. Barueri, SP: Manole, 2010.

INSTITUTO AKATU. Para termos água em nossas torneiras, precisamos combater as mudanças climáticas. 2016. Disponível em: <http://www.akatu.org.br/Temas/Mudancas-Climaticas/ Posts/Para-termos-agua-em-nossas-torneiras-precisamos-ajudar-a-combater-as-Mudancas-Climaticas>. Acesso em: 5 jul. 2016.

INSTITUTO SOCIOAMBIENTAL. O mundo está com febre. Disponível em: <https:// www.socioambiental.org/pt-br/noticias-socioambientais/o-mundo-esta-com-febre>. Acesso em: 20 jul. 2016.

KEMPF, Hervé. Como os ricos destroem o planeta. Tradução Bernardo Ajzenberg. São Paulo: Globo, 2010.

LAVRATTI, Paula; CAVEDON-CAPDEVILLE, Fernanda de Salles. Política Nacional sobre Mudança do Clima. In: LEITE, José Rubens Morato (Coord.). Manual de direito ambiental. São Paulo: Saraiva, 2015. p. 532.

LEFF, Enrique. Discursos sustentáveis. Tradução Silvana Cobucci Leite. São Paulo: Cortez, 2010.

LEITE, José Rubens Morato. Dano ambiental: do individual ao coletivo extrapatrimonial. 3. ed. São Paulo: Revista dos Tribunais, 2010. (Coord.). Manual de direito ambiental. São Paulo: Saraiva, 2015.

LIPOVETSKY, Gilles. A felicidade paradoxal: ensaio sobre a sociedade de hiperconsumo. São Paulo: Companhia das Letras, 2007. 
MACHADO, Paulo Affonso Leme. Direito ambiental brasileiro. 23. ed. São Paulo: Malheiros, 2015.

MARCOVITCH, Jacques. Para mudar o futuro: mudanças climáticas, políticas públicas e estratégias empresariais. São Paulo: Edusp, 2012.

MATIAS, Eduardo Felipe Pérez. A humanidade contra as cordas: a luta da sociedade global pela sustentabilidade. São Paulo: Paz e Terra, 2015.

MILARÉ, Édis. Direito do ambiente. 6. ed. São Paulo: Revista dos Tribunais, 2009.

MILlER JR., G. Tyler. Ciência ambiental. Tradução All Tasks. São Paulo: Cengage Learning, 2008.

MINISTÉRIO DO MEIO AMBIENTE. Plano de ação para produção e consumo sustentáveis. Brasília: MMA, 2011.

MIRAGEM, Bruno. Consumo sustentável e desenvolvimento: por uma agenda comum do direito do consumidor e do direito ambiental. Revista do Ministério Público do RS, Porto Alegre, n. 74, p. 229-244, jul./dez. 2013.

MORAES, Paulo Valério Dal Pai. Macrorrelação ambiental de consumo: responsabilidade pós-consumo ou relação coletiva de consumo? Porto Alegre: Livraria do Advogado, 2013.

MOTTA, Márcia (Org.). Dicionário da terra. 2. ed. Rio de Janeiro: Civilização Brasileira, 2010.

ONÇA, Daniela de Souza. "Quando o sol brilha, eles fogem para a sombra”: a ideologia do aquecimento global. 2011. 557 f. Tese (Doutorado em Geografia) - Universidade de São Paulo, São Paulo, 2011.

PAZ, Josi. O clima do consumo: a sociedade de consumidores no debate sobre a mudança climática. 2012.559 p. Tese (Doutorado em Sociologia) - Universidade de Brasília, Brasília, 2012.

PEREIRA, Agostinho Oli Koppe. Responsabilidade civil por danos ao consumidor causados por defeitos dos produtos: a teoria da ação social e o direito do consumidor. Porto Alegre: Livraria do Advogado, 2003.

PORTILHO, Fátima. Sustentabilidade ambiental, consumo e cidadania. São Paulo: Cortez, 2005.

RAMOS Jr., Dempsey Pereira. Meio ambiente e conceito juridico de futuras geraçôes. Curitiba: Juruá, 2012. 
RECH, Adir Ubaldo; BUTZKE, Alindo; GULLO, Maria Carolina (Org.). Direito, economia e meio ambiente: olhares de diversos pesquisadores. Caxias do Sul, RS: Educs, 2012.

ROSS, Jurandyr Sanches (Org.). Geografia do Brasil. São Paulo: Edusp, 2014. p. 83.

SARLET, Ingo Wolfgang; FENSTERSEIFER, Tiago. Direito ambiental: introdução, fundamentos e teoria geral. São Paulo: Saraiva, 2014.

SILVA, Christian Luiz da (Org.). Desenvolvimento sustentável: um modelo analítico integrado e adaptativo. 2. ed. Petrópolis, RJ: Vozes, 2008.

SODRÉ, Marcelo Gomes. Padrôes de consumo e meio ambiente. Revista de Direito do Consumidor, São Paulo: RT, v. 31, jul./set. 1999.

SOUZA FILHO, Carlos Frederico Marés de. De como a natureza foi expulsa da modernidade. Revista Crítica de Direito, São Paulo, v. 66, n. 5, p. 88-104, ago./dez. 2015.

STEINKE, Ercília Torres. Climatologia fácil. São Paulo: Oficina de Textos, 2015.

TAVARES, Fred; IRVING, Marta de Azevedo. Natureza S.A.: o consumo verde na era do ecopoder. São Carlos, SP: RiMa, 2009.

UNITED NATIONS. United Nations guidelines on consumer protection: as expanded in 1999. Genebra: Unctad, 2011. Disponível em: <http://unctad.org/en/Docs/poditcclpm21. en.pdf>. Acesso em: 12 jul. 2016.

VEIGA, José Eli da. Para entender o desenvolvimento sustentável. São Paulo: 34, 2015.

. "Não é que os empresários vejam a sustentabilidade como obstáculo; ela é mesmo um obstáculo". In: ARNT, Ricardo (Org.). O que os economistas pensam sobre sustentabilidade. São Paulo: 34, 2010. p. 149. 